University of Nebraska - Lincoln

DigitalCommons@University of Nebraska - Lincoln

1988

\title{
Cheilosia corydon (Diptera: Syrphidae)., a Candidate for the Biological Control of Musk Thistle in North America
}

\author{
Antonio Rizza \\ U.S. Department of Agriculture \\ Gaetano Campobasso \\ U.S. Department of Agriculture \\ Paul Dunn \\ U.S. Department of Agriculture \\ Massimo Stazi \\ U.S. Department of Agriculture
}

Follow this and additional works at: https://digitalcommons.unl.edu/entomologyother

Part of the Entomology Commons

Rizza, Antonio; Campobasso, Gaetano; Dunn, Paul; and Stazi, Massimo, "Cheilosia corydon (Diptera: Syrphidae)., a Candidate for the Biological Control of Musk Thistle in North America" (1988). Entomology Papers from Other Sources. 63.

https://digitalcommons.unl.edu/entomologyother/63

This Article is brought to you for free and open access by the Entomology Collections, Miscellaneous at DigitalCommons@University of Nebraska - Lincoln. It has been accepted for inclusion in Entomology Papers from Other Sources by an authorized administrator of DigitalCommons@University of Nebraska - Lincoln. 


\title{
Cheilosia corydon (Diptera: Syrphidae), a Candidate for the Biological Control of Musk Thistle in North America
}

\author{
ANTONIO RIZZA, GAETANO CAMPOBASSO, PAUL H. DUNN, \\ AND MASSIMO STAZI \\ U.S. Department of Agriculture, Agricultural Research Service, \\ Biological Control of Weeds Laboratory-Europe, \\ American Embassy, Agriculture, APO New York 09794.
}

\begin{abstract}
Ann. Fntomol Soc Am 81(2): 225-232 (1988)
ABSTRACT In Italy, larvae of the syrphid fly, Cheilosia corydon (Harris) (=grossa Fallén), infest the flower buds, stems, and roots of Carduus nutans L. and C. pycnocephalus $\mathbf{L}$. (Compositae), both serious weeds in the United States. The fly was studied as a candidate biological control agent of musk and Italian thistle in North America. The host range of $C$. corydon is narrow, restricted to plants of the tribe Cardueae. Cirsium crassicaule (Green) Jeps., a threatened U.S. species, was marginally suitable as a host in laboratory trials. In open-field oviposition tests, using replicated and randomized plantings, no oviposition was observed on any U.S. Cirsium species tested, including C. crassicaule. Our data indicate that C. corydon is sufficiently host specific to introduce into the U.S. for the biological control of musk and Italian thistle.
\end{abstract}

KEY WORDS Insecta, Cheilosia corydon, thistle, biological control

MUSK THISTLE was probably introduced into the United States from Europe. First recorded in the U.S. in 1853 at Harrisburg, Pa. (Stuckey and Forsyth 1971), it has since become an important weed in pastures and rangelands in the U.S. and Canada, with the largest and most severe infestations in the Appalachian and midwest regions (Dunn 1976). When established in pastures, the weed competes with desirable plants and limits the use of these areas by livestock or for recreational purposes because of spines on the leaves, stalks, and blooms (Dunn 1976).

There is some taxonomic confusion in the genus Carduus in North America. Musk thistle is probably C. nutans subsp. leiophyllus (Petrovich) Stoj. and Stef., and C. $n$. subsp. macrocephalus (Desf.) Nyman (see McGregor 1986).

The first attempt at biological control of musk thistle used Rhinocyllus conicus Froelich, an introduced weevil that oviposits on the bracts of thistle heads and whose larvae feed in the receptacle, destroying the seeds. In 1969 this weevil was released in Montana (Rees 1977) and Virginia (Surles et al. 1974); it is now well established in several states in the U.S. (Trumble and Kok 1982). A second weevil, Trichosirocalus horridus (Panzer), whose larvae damage thistle rosettes, was released in the U.S. in 1974, and Kok and Trumble (1979) confirmed its establishment in Virginia.

In spite of these successful introductions, musk thistle is still an important pest, and other natural enemies are needed to occupy the unexploited niches and stress the weed even more.

A third natural enemy of Carduus nutans and C. pycnocephalus L. in most of Europe is a phy- tophagous syrphid fly, Cheilosia corydon (Harris) (=grossa Fallén).'

The best English description of the adults of $C$. corydon (as grossa) was provided by Verrall (1901); the larvae and puparia were described by Dusek and Laska (1962). The fly is widely distributed throughout Europe (Rondani 1857, Becker 1894, Séguy 1961, van Leeuwen 1983), and we have new records from Yugoslavia, Bulgaria, and Turkey. Despite its wide distribution, no literature records C. corydon as a pest of cultivated plants (Anonymous 1913-73, Della Beffa 1961, Balachowsky 1963). This encouraged us to conduct life history and host specificity studies of $C$. corydon at the Biological Control of Weeds Laboratory, Rome, Italy, from 1980 to 1984.

\section{Cheilosia spp. Associated with Thistles}

Smith (1979) reports that the genus Cheilosia Meigen contains about 130 Palearctic species, while F. C. Thompson (personal communication) indicates this number to be much higher. Immature stages of only a few of these species have been described. Many of the larvae are phytophagous, feeding on fungi or in stems of angiosperm plants, often Compositae. Séguy (1961), Smith (1979), and Batra et al. (1981), quoting earlier references, listed those Cheilosia species that have been recorded on various thistles. The host of Cheilosia vulpina (Mei-

1 According to F. C. Thompson (personal communication), Cheilosia grossa Fallén is now correctly known as C. corydon (Harris), a prior name. 
gen) is not recorded, but collection records of the Rome Laboratory show that its larvae were found mining roots and crowns of Cirsium arvense (L.) Scop., C. palustre L., and another Cirsium sp. Zwölfer (1965) also noted Cheilosia spp. larvae on Carduus and Cirsium thistles. Recently, Zwölfer's material was identified by F. C. Thompson as follows:

Fifteen larvae collected from Carduus nutans at Viener Neustaat, Austria; Aalen, Germany; and Colmar, France between 8 and 29 May 1962-63, were all Cheilosia corydon. Larvae collected from Cirsium palustre 31 May 1962 at Karlsruhe, and 2 July 1963 at Erlangen, Germany, were Cheilosia vulpina. Of three larvae collected at Graz, Austria 7 August 1962 from Cirsium oleraceum (L.) Scop., one was $C$. proxima Zetterstedt and the other two could not be identified, but they were not C. corydon. A single larva from Cirsium vulgare (Savi) Ten., collected 1 September 1964 at Erlangen, Germany, was identified as C. corydon.

Cheilosia corydon (as grossa) has been recorded from various thistles. Nurse (1910) reported larvae in the basal portion of stems of Cnicus palustris (L.) Willd. In August; Mellini (1951) reported larvae overwintering in roots of Carduus nutans and C. pycnocephalus, the adults emerging in March; Dusek and Laska (1962) found larvae in stems of Carduus crispus L.; Boldt (1978) reported that larval C. corydon feed in stems and roots of Carduus nutans; Van Leeuwen (1983) recorded C. corydon on Cirsium palustre and C. vulgare. We have collected Cheilosia corydon larvae in many locations in Italy and Europe (from sea level to I,300 m), most in stems and roots of the musk thistle group (Carduus nutans, C. macrocephalus, C. thoermeri) and Carduus pycnocephalus. However, in our collection we have one larva of $C$. corydon found on Cirsium eriophorum (L.) Scop. and another from Cirsium vulgare.

\section{Materials and Methods}

Life History. The seasonal sequence of C. corydon life stages was followed during 1980-82 at Castelporziano, the Presidential Hunting Preserve near Rome, Italy. This 5,000-ha preserve has a good infestation of musk thistle ${ }^{2}$ and a high population of C. corydon. In July 1980, 100 C. macrocephalus Desf. plants infested with C. corydon larvae were marked by placing an iron rod in the ground ca. $5 \mathrm{~cm}$ from the crown of each plant. The rod extended above ground ca. $30 \mathrm{~cm}$, making it easy to relocate mature plants, whose aerial parts die in the summer and disintegrate during the winter. In late October 1980, mature $C$. corydon larvae $(n=$ 21) collected from roots of previously marked, dead

${ }^{2}$ The most common form in Castelporziano is Carduus macrocephalus Desf. spp. inconscrictus (O. Schw.) Kaz. (det. Kazmi 1976).
C. macrocephalus plants were placed in soil (3-5 $\mathrm{cm}$ deep) at Castelporziano under a (50 by 50 by $50 \mathrm{~cm}$ ) screen cage, to collect emerging flies in the spring. The oviposition period was studied during the 1981 and 1982 flight seasons (March-April) by inspecting 100 randomly selected C. macrocephalus rosettes for eggs every other day. Any eggs found on the leaves were recorded, then crushed; thus, it was possible to determine the duration of peak oviposition period, average number of eggs per plant, and percent infestation. Every $2 \mathrm{wk}$, from April to November 1981, 20 C. macrocephalus plants were dissected to follow larval development. Duration of stadia was studied from April to November 1981 in an outdoor insectary by putting one neonate larva on each of 15 rosette centers (shoots) of C. macrocephalus plants excised from the parent plant and held individually in $175-\mathrm{ml}$ plastic cups.

Infested shoots were dissected on Mondays, Wednesdays, and Fridays. Each dissected shoot was replaced with a fresh one, and the larva was placed inside a fresh shoot after its molts were recorded. After a larva became third instar, food was replaced weekly until pupation.

Larval Survival Tests (Laboratory). Field-collected eggs were transferred to 40 plant species in 6 families (Table 1). Plants were selected because they were 1) closely related to the target weed; 2 ) hosts of congeneric species of Cheilosia corydon; 3 ) crops in the same family as the target weed; 4) American biotypes of the target weed; and 5) native U.S. plants related to the target weed, including Cirsium crassicaule (Greene) Jeps., an endangered species.

Italian plants used in this experiment were grown in a laboratory greenhouse like cultivated and native U.S. plant species or were transplanted from the field as young plants. Plants used in the test were all large enough (rosette diameter, $21-41 \mathrm{~cm}$ ) to support one or more larvae to pupation. The plants were kept in an outdoor insectary during the test and grown in garden soil in $22-\mathrm{cm}$ diameter terra-cotta pots placed on plastic saucers and watered from below so eggs placed on the plants would not be disturbed. Each species tested was replicated five times (one plant per one replicate) and each replicate was infested with five eggs. Chorions of all hatched eggs were recovered to quantify the percentage of eclosion.

The larval survival test began on 6 April 1982 and ended 2 mo later, when all the plants were dissected. A similar test in 1984 used the same technique, testing U.S. biotypes of musk thistle and other Carduus species.

Oviposition Preference (Field). Two field tests were conducted to ascertain the oviposition preference of Cheilosia when given a choice between their natural hosts and U.S. Cirsium species. In designing these open-field oviposition tests, we wanted to increase the probability that the test plants would be visited by ovipositing flies. 
Table 1. Survival of first instars on several plants (laboratory)

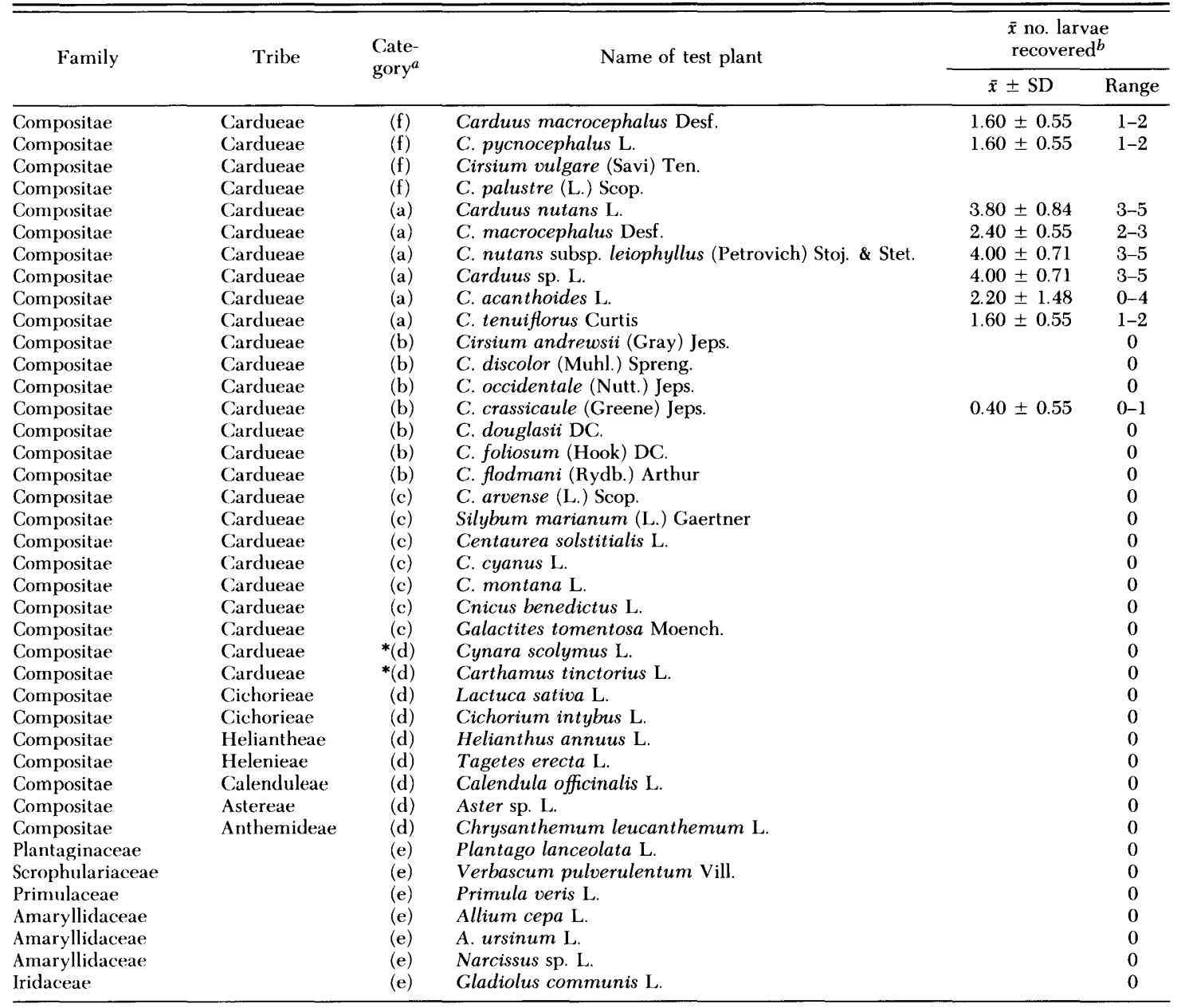

a Category of test plants: (a), U.S. biotypes of the target weed (tested in 1984); (b), U.S. native plants closely related to the target; (c), weed closely related to the target; (d), crop in the same family as the target weed; (e), host of other Cheilosia spp.; (f), recorded host; *, U.S. cultivars.

${ }^{b}$ Mean number of $C$. corydon larvae dissected from single plants (five replicates) on which five eggs per plant were placed and checked for eclosion and larval survival. Dissections were made ca. $60 \mathrm{~d}$ after hatch.

Test A was designed to encourage ovipositing Cheilosia to lay eggs on various potted Cirsium species placed in the ground near musk thistle plants growing naturally in the area. Later, after finding eggs on the natural host (musk thistle), we started Test $\mathrm{B}$ by removing the natural host and leaving only Cirsium test plants, thus avoiding any influence of naturally occurring musk thistle on the host selection and oviposition on test plants.

Test A. A $500-\mathrm{m}^{2}$ plot $(20$ by $25 \mathrm{~m}$ ) at Castelporziano in an area with a known C. corydon population was chosen. Each naturally growing musk thistle plant in the plot $(n=115)$ was numbered and indicated on a plot map (Fig. 1). From these, 24 were randomly selected as "attraction plants." Four potted plants (replicates) of each of six U.S. Cirsium species (24 plants) were used as test plants. The test plants and control plants $(n=24)$ were grown from seed in a greenhouse, potted, and placed in the ground near an attraction plant with the top of the pot at ground level. At the beginning of the experiment (29 March 1982), diameters of the rosettes of plants in the experiment were measured and recorded (Table 2), to determine if the behavior of the fly had been influenced by unusually large or small rosettes. A potted U.S. Cirsium test plant and a potted C. macrocephalus control were randomly assigned to each attraction plant; i.e., a naturally occurring C. macrocephalus was left in place in the field. Locations of the test and control plants in relation to the attraction plant were randomly selected from one of four predetermined positions (Fig. 2). Plants were placed in a triangle pattern with $30 \mathrm{~cm}$ between the extremities of the peripheral leaves of each rosette. Every $2 \mathrm{~d}$ all plants were carefully examined and any eggs found 


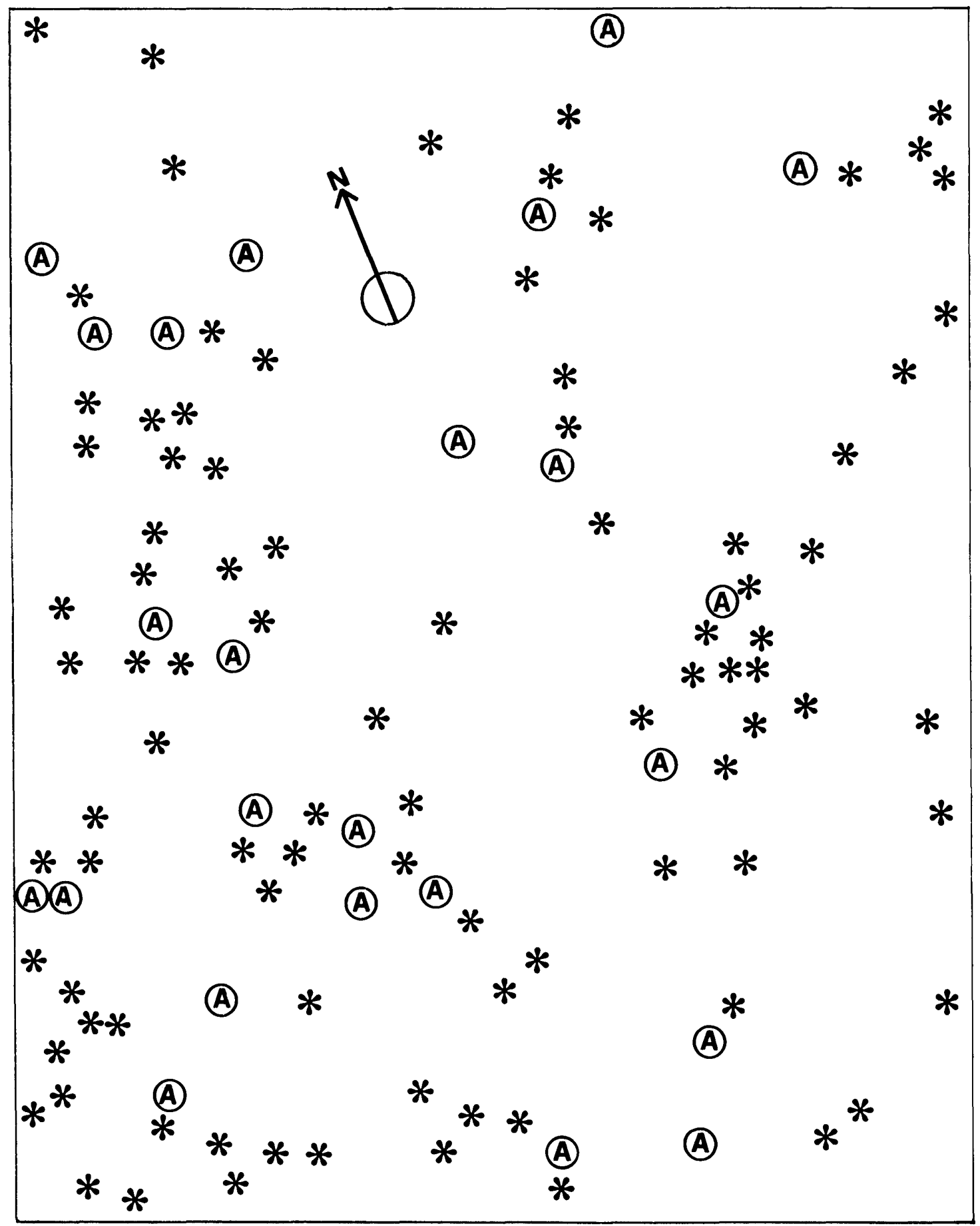

$$
\text { Legend: } \begin{aligned}
\mathbf{N} & =\text { north } \\
* & =\text { naturally growing Musk thistle plants } \\
\mathbb{A} & =\text { naturally growing Musk thistle plants } \\
& \text { randomly selected as "attraction plants" }
\end{aligned}
$$

Fig. 1. Map of $500-\mathrm{m}^{2}$ musk thistle plot at Castelporziano showing distribution of the designated attraction plants. 

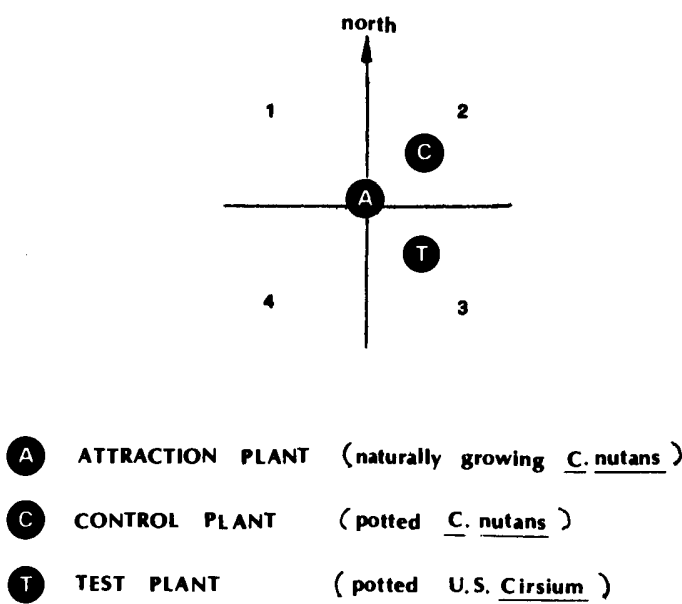

Fig. 2. Diagram of the attraction plant position with a test plant and a control plant each randomly assigned to one of the four positions indicated.

were removed after recording their number and position, except on the last examination (13 April). Test plants and controls were exposed to flies during the peak oviposition period, 29 March to 13 April 1982. After exposure, all plants were removed from the field plot, transferred to the laboratory garden, left undisturbed in pots for 2 mo, then dissected to check the presence and growth of $C$. corydon larvae.

Test B. On 29 March 1982 a $288-\mathrm{m}^{2}$ plot (12 by $24 \mathrm{~m}$ ) was set up $50 \mathrm{~m}$ from the Test A plot. The plot was divided into 32 sub-plots each $9 \mathrm{~m}^{2}$ ( 3 by $3 \mathrm{~m})$. A potted test or control plant was randomly assigned to, and placed in the center of each subplot, and the pot was buried with the top at ground level. Four potted plants (four replicates) of each of seven U.S. Cirsium species were the test plants and four replicates of a musk thistle control were used. The musk thistles (attraction plants) naturally growing in the sub-plots $(n=75)$ were mapped and left in situ to be examined for eggs to ascertain that the area had been visited by $C$. corydon adults. Some eggs were found on attraction plants, so all naturally growing musk thistle plants were removed. Every $2 \mathrm{~d}$ during the exposure period, test plants and controls were examined and eggs were counted, recorded, and removed. After $15 \mathrm{~d}$ exposure, on 13 April, test and control plants were transferred from the field to the laboratory garden and left undisturbed until dissected 2 mo later to check for larval survival. This test was repeated in 1984 using only Cirsium crassicaule plants $(n=$ 15) to increase its exposure to the ovipositing flies.

Dissection of Naturally Occurring Weedy Thistles (Field). To determine the natural host range of C. corydon, we dissected 50 or 100 plants of each of several thistle species growing in a mixed population with infested musk thistle at Castelporziano (elevation, sea level), In addition, 100
Table 2. Diameter of rosettes of six species of Cirsium test plants, musk thistle controls, and musk thistle attraction plants used in open-field tests with $C$. corydon at Castelporziano, Rome, Italy; Test A

\begin{tabular}{ccc}
\hline \hline \multicolumn{2}{c}{ Plant rosettes (mean diam cm) $(n=4) \bar{x} \pm \mathrm{SD}^{a}$} \\
\hline $\begin{array}{c}\text { Test plants: } \\
\text { potted Cirsium } \\
\text { spp. }\end{array}$ & $\begin{array}{c}\text { Control plants: } \\
\text { potted musk } \\
\text { thistle }\end{array}$ & $\begin{array}{c}\text { Attraction plants: } \\
\text { naturally growing } \\
\text { musk thistle }\end{array}$ \\
\hline $30.75 \pm 3.30 \mathrm{a}$ & $34.25 \pm 8.42$ & $47.25 \pm 29.45$ \\
$(26-33)$ & $(26-42)$ & $(16-83)$ \\
$28.50 \pm 1.73 \mathrm{~b}$ & $31.00 \pm 2.58$ & $68.25 \pm 13.87$ \\
$(26-30)$ & $(28-34)$ & $(50-80)$ \\
$26.25 \pm 4.50 \mathrm{c}$ & $35.25 \pm 4.27$ & $43.75 \pm 11.93$ \\
$(20-30)$ & $(30-40)$ & $(32-55)$ \\
$20.75 \pm 1.71 \mathrm{~d}$ & $32.75 \pm 7.14$ & $53.50 \pm 12.77$ \\
$(19-23)$ & $(25-41)$ & $(\mathbf{4} 3-72)$ \\
$33.50 \pm 2.38 \mathrm{e}$ & $34.25 \pm 2.06$ & $39.00 \pm 10.00$ \\
$(30-35)$ & $(32-36)$ & $(26-50)$ \\
$33.25 \pm 6.18 \mathrm{f}$ & $35.25 \pm 2.99$ & $46.75 \pm 17.54$ \\
$(25-38)$ & $(32-39)$ & $(30-68)$ \\
\hline
\end{tabular}

${ }^{a}$ Ranges are values in parentheses.

${ }^{b}$ a, C. discolor; b, C. occidentale; c, C. douglasii; d, C. foliosum; $\mathrm{e}$, C. crassicaule; $\mathrm{f}, \mathrm{C}$. andrewsii.

plants of each of several thistle species growing intermixed with $C$. corydon-infested musk thistle in Sila, Calabria (elevation, 1,300 m), were dissected on the site. Larvae found in both dissections were preserved in $70 \%$ ethyl alcohol for later identification, and herbarium sheets of thistles at both sites were prepared for later confirmation of their identity.

Voucher specimens of C. corydon from Castelporziano have been deposited in U.S. Museum of Natural History, Washington, D.C.

\section{Results}

Life History. Adults from the larvae put in the field cage in October 1980 emerged between 27 February and 2 March 1981, indicating the flies should then be flying in the open field. After $3 \mathrm{~d}$ of unsuccessful searching for the flies on musk thistle rosettes, we observed two adults flying near flowering plants of Asphodelus ramosus L. (Liliaceae), Because Asphodelus is one of the few plants in the area which flowers in this period, it is possible that $C$. corydon adults visit its flowers to feed.

In 1981, the first eggs $(n=2)$ were found on 10 March, and peak oviposition occurred around 24 March, with a mean of $5.9 \pm 7.9(\bar{x} \pm$ SD) eggs per infested plant (range, $1-60$ ); $64 \%$ of the plants had eggs. The last egg was found 2 April. In 1982 , the first eggs $(n=8)$ were found on 26 March; peak oviposition occurred about 10 April, with a mean of $3.92 \pm 3.93$ eggs (range, 1-20) per infested plant. Sixty percent of the plants had eggs and the oviposition cycle ended on 19 April.

Eggs were laid on the young, hirsutulous leaves and young shoots, usually at the center of the plant. The tangled leaves and shoots appear to protect the eggs from parasites, predators, exposure to the sun, and provide a humid niche which prevents 
Table 3. Percent infested plants and number and species of larvae per plant dissected from various thistle species in fields where $C$. corydon was present at Rome and in the Sila, Calabria, Italy

\begin{tabular}{|c|c|c|c|}
\hline Plants dissected & $\begin{array}{l}\text { No. plants } \\
\text { dissected }\end{array}$ & $\begin{array}{l}\% \text { plants } \\
\text { infested }^{a}\end{array}$ & $\begin{array}{c}\text { Larvae per plan } \\
\bar{x} \pm \mathrm{SD} \text { (range) }\end{array}$ \\
\hline \multicolumn{4}{|c|}{ Castelporziano, Rome } \\
\hline Carduus macrocephalus Desf. & 50 & $70 \mathrm{a}$ & $\begin{array}{c}2.44 \pm 1.89 \\
(1-7)\end{array}$ \\
\hline Carduus pycnocephalus L. & 50 & $36 a$ & $\begin{array}{c}1.71 \pm 0.86 \\
(1-4)\end{array}$ \\
\hline Galactites tomentosa Moench & 50 & & \\
\hline Onopordum acanthium L. & 50 & & \\
\hline Silybum marianum (L.) Gaertner & 50 & & \\
\hline Cirsium arvense (L.) Scop. & 50 & & \\
\hline Cirsium vulgare (Savi) Ten. (=C. lanceolatum (L.) Scop.) & 50 & & \\
\hline Cirsium eriophorum (L.) Scop. & 50 & & \\
\hline Sonchus oleraceus $\mathrm{L}$. & 50 & & \\
\hline Echinops sphaerocephalus $\mathrm{L}$. & 50 & & \\
\hline Carlina acaulis $\mathrm{L}$. & 50 & & \\
\hline Cynara cardunculus L. & 50 & & \\
\hline \multicolumn{4}{|c|}{ Sila, Calabria } \\
\hline Carduus macrocephalus Desf. & 100 & $41 \mathrm{a}$ & $\begin{array}{c}1.72 \pm 0.79 \\
(1-4)\end{array}$ \\
\hline Cirsium vulgare (Savi) Ten. & 100 & $1 \mathbf{a}$ & $\begin{array}{c}0.01 \pm 0.10 \\
(0-1)\end{array}$ \\
\hline Cirsium arvense (L.) Scop. & 100 & & \\
\hline Cirsium prob. palustre (L.) Scop). & 100 & $13 b$ & $\begin{array}{c}1.46 \pm 0.66 \\
(1-3)\end{array}$ \\
\hline Cirsium sp. & 100 & $9 \mathrm{c}$ & $\begin{array}{c}1.78 \pm 1.64 \\
(1-6)\end{array}$ \\
\hline Onopordum acanthium $\mathrm{L}$. & 100 & & \\
\hline Carlina acaulis $\mathrm{L}$. & 100 & & \\
\hline
\end{tabular}

${ }^{a}$ Species of larvae recovered: a, C. corydon; b, C. vulpina and C. cynocephala; c, C. vulpina

${ }^{b}$ Ranges are values in parentheses.

desiccation. Eggs were usually laid singly but could also be found in groups of three or four. When freshly deposited, the egg is elongate $(1.2 \pm 0.04$ by $0.48 \pm 0.02 \mathrm{~mm} ; n=30$ ), whitish but becoming darker with age. At outdoor temperatures, the eggs required $6.4 \pm 0.7 \mathrm{~d}(n=85)$ to hatch.

There were three instars. Out-of-doors, the larvae needed $11.20 \pm 0.6 \mathrm{~d}$ to reach the second instar and $6.7 \pm 1.3 \mathrm{~d}$ to reach third instar, which fed until November, then pupated.

In nature, newly hatched larvae mine directly into tender, young shoots. As the shoots grow, the second and third instars, often more than one, enter the stem and mine up and down; then in late April and early May they tunnel downward into the more compact tissue, working toward the root.

Of 20 musk thistle plants at Castelporziano chosen at random and dissected on 29 April 1981, 13 $(65 \%)$ contained $3.7 \pm 4.4$ (range, $1-29)$ Cheilosia larvae. The mean number of shoots per plant was $6.9 \pm 3.9$, and the mean number of infested shoots per plant was $3.08 \pm 3.8$.

During summer, when the plant senesces, larvae have already reached the crown and root, where they remain quiescent until fall rains begin. Damage caused by larval feeding is clearly evident; many infested stems are broken and prematurely dried, often with the immature inflorescence at tached. Stresses on infested plants include interruption of the moisture and nutrient transport system, loss of infloresences (hence lower seed production), and the opening of lesions on the root allowing introduction of soil microorganisms. When more than one larva reaches the root, the plant often dies.

Larval Starvation. In this test, the host range of C. corydon was narrow, including only plants of the genus Carduus and Cirsium crassicaule (Table 1); the latter may be only a laboratory induced artifact. Only two of the five C. crassicaule plants in the test had larvae (one larva per plant).

Carduus macrocephalus and C. pycnocephalus are known European hosts, and all "forms" of the musk thistle complex were suitable hosts. Carduus acanthoides L. and C. tenuiflorus are weeds of some importance in the U.S., and are also acceptable as hosts. No other plants in the test were damaged by larval feeding. Cirsium palustre and C. vulgare, the other recorded hosts, were not suitable hosts in our tests. Most questionable literature records may be attributed to incorrect identification of the plant or insect. However, the records of $C$. corydon on C. palustre and C. vulgare of Nurse (1910) and van Leeuwen (1983) have been verified by F. C. Thompson (personal communication), who has re-examined the specimens on which these records were based.

Oviposition. Results of these field trials were very favorable. In Test A, $91.7 \%$ of attraction plants and $95.8 \%$ of controls had eggs, whereas no eggs were found on any of the 24 test plants. Clearly the naturally growing attraction plants did not dis- 
tract flies from ovipositing on potted controls. Nonoviposition on Cirsium plants cannot be ascribed to rosette size because the mean sizes of the test plant rosettes and their respective controls were about the same (Table 2). It was also noted, 2 mo later, that $91.7 \%$ of the musk thistle control plants $(n=16)$ had $1.6 \pm 0.7$ C. corydon larvae per plant, but the Cirsium spp. had no larvae.

In Test $\mathrm{B}$, eggs were found on eight attraction plants on 31 March and on another 15 plants on 2 April. After removal of the naturally occurring attraction plants, no test plants were accepted for oviposition by C. corydon, but all plants in the control had eggs. When all plants were dissected 2 mo later, larvae were found only in the controls $(2.75 \pm 0.50$ per plant). In the 1984 experiment no eggs were found on additional Cirsium crassicaule plants $(n=15)$, but all musk thistle plants in the control had eggs.

Dissection of Weedy Thistles. At Castelporziano, C. corydon larvae were found only on known hosts (Table 3). In Sila, Calabria, Carduus pycnocephalus was not present, but $41 \%$ of the musk thistle plants were infested with $C$. corydon larvae (1.7 \pm 0.8 larvae per plant). Our records show a single $C$. corydon larva was also found during the dissection of 100 Cirsium vulgare plants.

Mortality Factors. One thousand $C$. corydon eggs, collected intermittently from the field during the 1981 and 1982 oviposition periods, were held (50 per cup) in small plastic hatching cups (Rizza 1977) to capture any emerging parasites. No parasites emerged. However, an estimated $10 \%$ of the field-collected larvae were parasitized by Phydageuon sp. ${ }^{3}$ (Hymenoptera: Ichneumonidae).

\section{Discussion}

Of the phases of host-plant selection by an insect, oviposition (acceptance) is unquestionably the key step. When host acceptance is frustrated by tests in cages which may confound the ability of females to recognize the host, or bypassed by manually placing neonate larvae on nonhost test plants, many such plants may be suitable because they are not toxic to the larvae and have the required nutrients (much like a meridic diet) for larval growth and maturation.

Cirsium crassicaule is a marginally suitable laboratory host of C. corydon. Two of 25 neonate larvae lived to the third stadium when transferred to C. crassicaule. In an open-field oviposition experiment, in an area with a high C. corydon population and using replicated, randomized plantings of North American Cirsium spp. (including crassicaule), oviposition occurred only on the Carduus macrocephalus control plants.

Boldt (1978) reported some feeding by Cheilosia grossa (=corydon) larvae on several plants other than Carduus. However, his technique of placing

\footnotetext{
${ }^{3}$ Determined by Robert W. Carlson.
}

field-collected larvae directly into the test plants does not give a true picture of the insects' host range, which is limited by selective oviposition.

The introduction of any exotic organism into a new environment may present some risk. However, C. corydon presents less risk to native thistles in North America than the two weevils Rhinocyllus conicus (Froelich) and Trichosirocalus horridus (Panzer) already introduced. Prior to their introduction both species were recorded from various European thistles, including Cirsium spp. (Batra et al. 1981).

From the information now available we feel that C. corydon could be an effective biological control agent if introduced, because:

1) The fly has a limited host range.

2) The insect, feeding in both stems and roots, is a highly effective natural enemy of its host plants.

3) It will not compete with the weevils Rhinocyllus conicus and Trichosirocalus horridus, because it feeds on a different part of the plant.

4) The combined damage by several natural enemies at different times will stress the weeds over a longer period, resulting in loss of competitiveness and greater host plant mortality.

5) The insect will also be useful against two other weeds of economic importance in the United States (Dunn 1976) -Italian thistle (Carduus pycnocephalus), and plumeless thistle (Carduus acanthoides).

Also, because the fly is common in Europe in a range of climates similar to those where U.S. Carduus spp. infestations are found, there should be minimal difficulty in establishing the fly in North America.

In addition to the obvious damage caused to the host plant by the fly, it earned a score of 30 when its potential effectiveness was evaluated by the Harris (1973) system. This high score reinforced our judgement that $C$. corydon would be an effective biological control agent if it is introduced.

\section{Acknowledgment}

This work is dedicated to the memory of Gianlauro Costantini Scala, former Director of the Castelporziano Presidential Hunting Preserve, whose cooperation made the project possible. We also thank Giovanni Emiliani, Director of Castelporziano; Guido Pezzali; Enzo Valentini; the Italian Ministry of Agriculture for permission to grow nearctic plant species in Italy; M. K. McCarty (ARS-USDA, University of Nebraska, Lincoln) for furnishing U.S. plant material; H. Zwölfer (University of Bayreuth, West Germany) for furnishing the Cheilosia specimens; F. C. Thompson (Systematic Entomology Laboratory, ARS-USDA, Beltsville, Md.) for his counsel on taxonomy and review of the manuscript; J. P. Lyon (Institut National de la Recherche Agronomique, Antibes, France) and Robert Carlson (Systematic Entomology Laboratory, ARS-USDA, Beltsville) for taxonomic assistance; T. Mimmocchi, F. Murano, and M. Cristofaro of this laboratory for assisting with the fieldwork; and Sara Rosenthal (ARS-USDA, Albany, Calif.), 
L. T. Kok (V.P.I. and State University, Blacksburg, Va.), Rod Bovey (ARS-USDA, Texas A\&M University, College Station, Tex., and S. L. Clement of this laboratory for reviewing the manuscript.

\section{References Cited}

Anonymous. 1913-73. Review of applied entomology, series A, agriculture, vol. 1-61. Commonwealth Institute of Entomology, London.

Anonymous. 1979. Rare plant status report on Cirsium crassicaule (Greene) Jepson. California Native Plant Society, CNPS Taxon Code: CICR.

Batra, S. W. T., J. R. Coulson, P. H. Dunn \& P. E. Boldt. 1981. Insects and fungi associated with Carduus thistles (Compositae). U.S. Dept. Agric. Tech. Bull. 1616 .

Becker, T. 1894. Revision der Gattung Cheilosia Meigen. Nova Acta Acad. Caesar. Lep. Carol. 62: 194524.

Boldt, P. E. 1978. Habitat of Carduus nutans L. and two phytophagous insects, pp. 98-104. In T. E. Freeman [ed.], Proceedings, IV International Symposium on the Biological Control of Weeds.

Della Beffa, G. 1961. Diptera-Syrphidae, pp. 991995. In Gli insetti dannosi all'agricoltura, terza edizione. Hoepli, Milano.

Dunn, P. H. 1976. Distribution of Carduus nutans, C. acanthoides, C. pycnocephalus, and C. crispus in the United States. Weed Sci. 24: 518-524.

Dusek, J. \& P. Laska. 1962. Beitrag zur Kenntnis einiger Syrphiden Larven (Diptera, Syrphidae). Acta Soc. Entomol. Czech. (Cas. Czech. Spol. Entomol.) 59: 348-356.

Fiori, A. 1974. Nuova flora analitica d'Italia. II. Edagricole, Florence.

Harris, P. 1973. The selection of effective agents for the biological control of weeds. Can. Entomol. 105: 1495-1503.

Jourdhveil, P. 1963. Tribu des Ceuthorrhynchini, pp. 1006-1062. In A. Balachowsky [ed.], Entomologie appliquéeà l'agriculture, tome I, Coléoptères, vol. 2 . Masson, Paris.

Kazmi, S. M. A. 1964. Revision der gattung Carduus (Compositae). Teil II. Mitt. Bot. Staats. München, V 5: 279-550.

Kok, L. T. \& J. T. Trumble. 1979. Establishment of Ceuthorhynchidius horridus (Coleoptera: Curculion- idae), an important thistle-feeding weevil, in Virginia. Environ. Entomol. 8: 221-223.

MeGregor, R. L 1986. Carduus, pp. 895-897. In $\mathrm{T}$. M. Barkley [ed.], Great Plains Flora Association, Flora of the Great Plains. University Press of Kansas, Lawrence, Kans.

Mellini, E. 1951. Insetti del Carduus nutans L. Bologna Entomol. Bol. 187: 272-292.

Nurse, C. G. 1910. Notes regarding the breeding of Cheilosia grossa. Entomologist 43: 313-314.

Rees, N. E. 1977. Impact of Rhinocyllus conicus on thistles in southwestern Montana. Environ. Entomol. 6: 839-842.

Rizza, A. 1977. Comparison of Phrydiuchus spilmani and P. tau. Ann. Entomol. Soc. Am. 70: 7-10.

Rondani, C. 1857. Dipterologiae Italicae prodromus, vol. 3. Part II, Muscidae, Siphoninae et (partim) Tachininae. Parma

Séguy, E. 1961. Diptères Syrphides de l'Europe occidentale. Mém. Mus. Nat. Hist. Nat. (A, Zool.) 23: $1-248$.

Smith, K. G. V. 1979. The larva and puparium of Cheilosia bergenstammi Becker (Diptera: Syrphidae) with a summary of the known biology of the genus in Europe. Entomol. Rec. 91: 190-194.

Stuckey, R. L. \& J. L. Forsyth. 1971. Distribution of naturalized Carduus nutans (Compositae) mapped in relation to geology in northwestern Ohio. Ohio J. Sci. 71: 1-15.

Surles, W. W., L. T. Kok \& R. L. Pienkowski. 1974. Rhinocyllus conicus establishment for biocontrol of thistles in Virginia. Weed Sci. 22: 1-3.

Trumble, J. T. \& L. T. Kok. 1982 . Integrated pest management techniques in thistle suppression in pastures of North America. Weed Res. 22: 345-359.

van Leeuwen, B. H. 1983. The consequences of predation in the population biology of the monocarpic species Cirsium palustre and Cirsium vulgare. Oecologia 58: 178-187.

Verrall, G. H. 1901. Platypezidae, Pipunculidae and Syrphidae of Great Britain. In G. H. Verrall [ed.], British flies (q.v.), vol. 8. Gurney, Jackson, London.

Zwölfer, H. 1965. Preliminary list of phytophagous insects attacking wild Cynareae (Compositae) species in Europe. CIBC Tech. Bull. 6: 81-154.

Received for publication 9 July 1986; accepted 10 August 1987. 